\title{
Age, Growth and Reproductive Biology of the Garfish, Belone belone (Linnaeus, 1760) (Teleostei: Belonidae) in the Central Mediterranean Sea
}

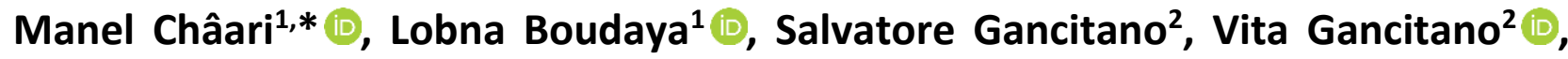 \\ Lassâd Neifar ${ }^{1}$
}

${ }^{1}$ University of Sfax, Faculty of Sciences of Sfax, Department of Life Sciences, Sfax, Tunisia.

${ }^{2}$ Italian National Research Council (CNR), Institute for Marine Biological Resources and Biotechnologies (IRBIM), Mazara del Vallo (TP), Italy.

\section{How to cite}

Châari, M., Boudaya, L., Gancitano, S., Gancitano, V., Neifar, L. (2022). Age, Growth and Reproductive Biology of the Garfish, Belone belone (Linnaeus, 1760) (Teleostei: Belonidae) in the Central Mediterranean Sea. Turkish Journal of Fisheries and Aquatic Sciences, 22(8), TRJFAS21161. http://doi.org/10.4194/TRJFAS21161

\section{Article History}

Received 13 December 2021

Accepted 15 February 2022

First Online 17 February 2022

\section{Corresponding Author}

Tel.: +0021655702260

E-mail: htchaari.m@gmail.com

\section{Keywords}

Belonidae

Belone belone

Biology

Central Mediterranean Sea

\begin{abstract}
Some aspects of the biology of the garfish Belone belone, were studied based on 453 specimens collected from the central Mediterranean (Tunisia). Total lengths ranged from 24.2 to $55 \mathrm{~cm}$ for females and from 25.8 to $52.5 \mathrm{~cm}$ for males, respectively. An overall sex ratio of $2.36 \div 1$ shows significant dominance of females in all size classes and seasons. Age data from otoliths reading revealed that females belonged to age groups from 1 to 4 years and males from 1 to 5 years. Most of the individuals were of age group 2. Length weight relationships and von Bertalanffy growth functions parameters were: $\mathrm{W}=0.0003 \mathrm{~L}^{3.419}, \mathrm{~L}_{\infty}=48.48 \mathrm{~cm}, \mathrm{k}=0.57$ year $^{-1}$ and $\mathrm{t}_{\mathrm{o}}=-1$ year for females and $W=0.0002 L^{3.530}, L_{\infty}=44.7 \mathrm{~cm}, k=0.67$ year $^{-1}$ and $t_{0}=-1$ year for males. Gonadosomatic index pattern indicated that spawning occurs once a year between March and May and extends to June with peak activity in March for both sexes. The length at the first maturity was estimated at a total length of $37.26 \pm 0.10 \mathrm{~cm}$ for females and $37.17 \pm 0.40 \mathrm{~cm}$ for males.
\end{abstract}

\section{Introduction}

The garfish, Belone belone (Linnaeus, 1760) is a marine belonids found in the eastern Atlantic Ocean and the Mediterranean Sea (Collette, 2003). Three subspecies were recognized by Collette and Parin (1970) according to their geographical distribution: $B$. b. belone (Linnaeus, 1761) restricted the North East Atlantic from Trondheim, Norway, the White Sea to the Ivory Coast and the South of the Cape Verde Islands (Collette \& Parin, 1970); B. b. gracilis Lowe, 1839 from the Mediterranean Sea and adjacent parts of the Atlantic Ocean, Madeira Sea, the Canary Islands, Azores and the Southern Cape Verde Islands (Collette, 2003) and B. $b$. euxini Günther, 1866 from the Black Sea and Sea of
Azov. Belone belone was recently reported as a valid endemic species from the eastern Atlantic and the Mediterranean Sea and B. euxini from the Black Sea, Sea of Azov and Sea of Marmara (Fricke et al., 2007; Froese \& Pauly, 2021).

Belone belone lives close to the surface, caught by casting or pelagic trawling and by floating gill nets (Nédélec, 1975; Collette, 2003). It has a migratory pattern similar to the mackerel (Froese \& Pauly, 2021). Garfishes are mainly found in offshore areas, but migrate into coastal regions during the spawning period where they are more susceptible to commercial exploitation (Jardas, 1996). In the Mediterranean areas, these species are considered one of the most commercial pelagic fish species in the Black sea artisanal 
fishery of Turkey with an average annual catch of about 442 tons in the decade between 2001 and 2012 (Bilgin et al., 2014 a) and also with a significant economic interest in Tunisia with a mean annual production of 230 tons between 2001 and 2010 (National fishery statistics of Tunisia). Garfish represent $80 \%$ of the total catch of belonids (500 tons in 2002) (Bedoui et al., 2002).

Studies about the biology of garfish $B$. belone have been carried out and published information still scarce in Central Western Mediterranean Sea. Dorman (1988, $1989,1991)$ reported information on some aspects of the biology, such as spawning time, age and growth, of $B$. belone from southern Ireland and Baltic Sea in the North East Atlantic. Samsun et al. (2006), Bilgin et al. (2014 a, b) and Ceyhan et al. (2019) studied the population structure, age, growth and reproductive biology of $B$. euxini from the Black Sea. In the Mediterranean Sea, Uçkun et al. (2004) reported data on the growth of $B$. belone from the Aegean Sea. Zorica et al. (2011) studied the spawning time and size at sexual maturity of $B$. belone from the Adriatic Sea. Data on the age, growth and mortality of $B$. belone from the Adriatic were given by Zorica and Čikeš Keč (2013). In Tunisian coasts, Bedoui et al. (2002) studied the spawning season and size at first maturity of $B$. belone. Then, the age and growth were established by Fehri-Bedoui and Gharbi (2004) analyzing the length frequency distributions. Two stocks of $B$. belone, one in the central and another in southern coasts off Tunisia, were discriminate using parasites as a tool (Châari et al., 2015). The present study aims to improve overall knowledge on the biology of $B$. belone from the Central Mediterranean at the eastern coast of Tunisia. The reproductive biology, sexual cycle, spawning period, the length at the first sexual maturity as well as age and growth have been analyzed and results were compared to those available in the literature. This study may be helpful that ensure the sustainability of species exploitation.

\section{Materials and Methods}

During the sampling period between 2004 and 2009, a total of 453 specimens of Belone belone were randomly collected. Specimens were caught by local coastal fishermen using mainly purse seine in the center and beach seine in the south eastern coast of Tunisia (Figure 1).

Belone belone is not available and completely absent from fish landings in November, December and January.

Fishes were identified using Collette and Parin (1970). Total length (TL) was recorded to the nearest $0.01 \mathrm{~cm}$. Total body (W), eviscerated body (We), gonads $(\mathrm{Wg})$ and livers (WI) were weighed to an accuracy of 0.01 $\mathrm{g}$ using digital balance.

The length-weight relationship was estimated by sex according to the standard allometric equation:

$$
W=a \times T L^{b}
$$

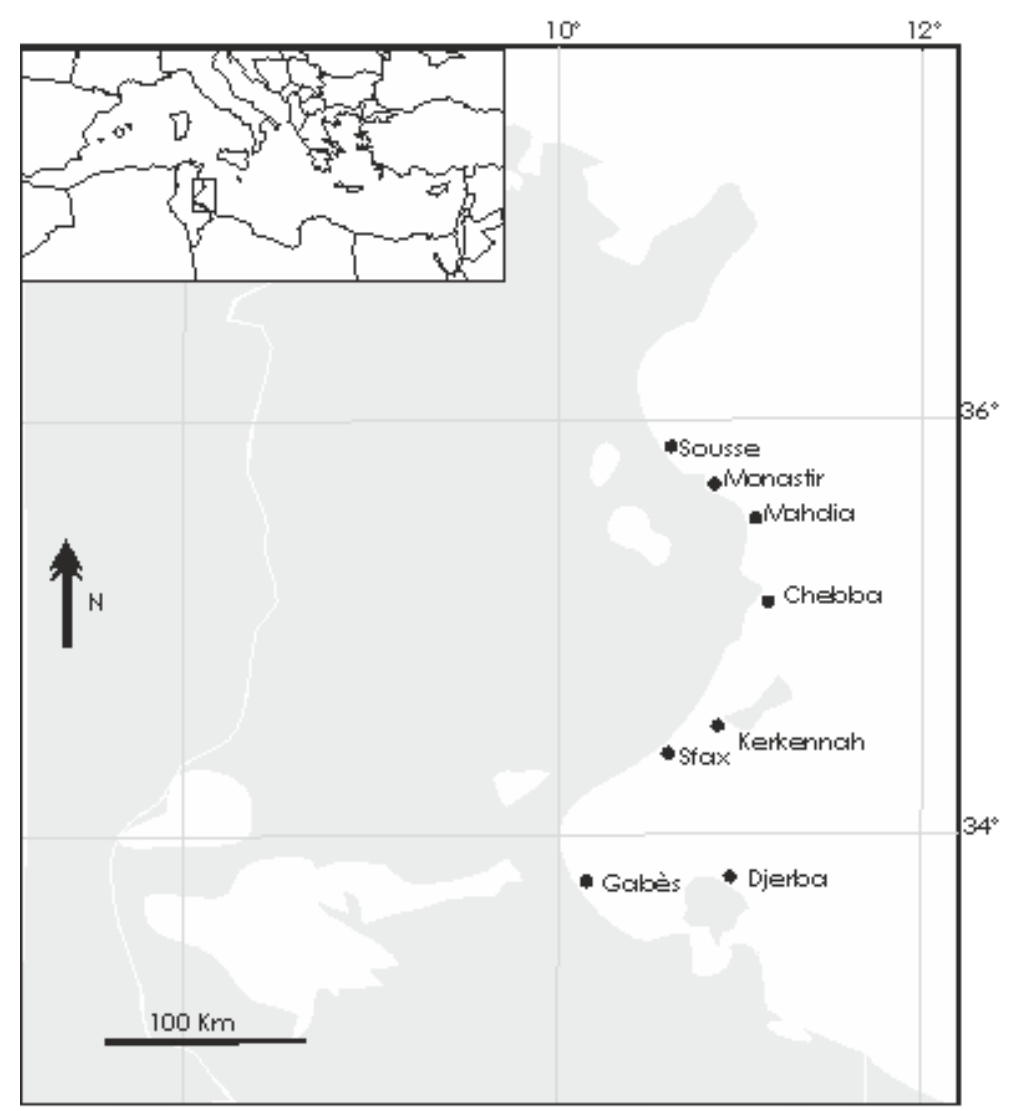

Figure 1. Sampling localities of garfish B. belone from off Tunisia (Central Mediterranean Sea) 
Relationship coefficients a and b were calculated using non-linear least squares estimation. Differences between sexes were tested by the analysis of covariance (ANCOVA). Before analysis, both length and weight were log 10-transformed to achieve linearity.

Sex and gonad maturity stages were assessed macroscopically for each specimen followed by a squatch for juveniles to distinguish males from females. Variations in the sex ratio were calculated according to sizes, months and seasons and results were compared using the $\chi^{2}$-test (Scherrer, 1984).

Four maturity groups were identified using sexual maturity scales as defined by Sinovčvić (1978) and Sinovčvić et al. (2008) that recognized 8 stages then modified and combined by Zorica et al. (2011) for belonids $B$. belone: immature (Stage I and stage II), maturing (Stage III and IV), ripe and spawning (Stage V and Stage VI), spent (Stage VII and Stage VIII). Monthly variations in maturity stages were determined.

In order to evaluate the gonadal development during the annual sexual cycle and to determine the reproductive period, the monthly gonadosomatic index (GSI) was calculated for males and females, as follows:

$$
\mathrm{GSI}=(\mathrm{Wg} / \mathrm{We}) \times 100
$$

The monthly hepatic-somatic index (HSI) and the condition factor $(\mathrm{K})$ were also estimated for each sex using the following formulas:

$$
\begin{aligned}
H S I & =(W I / W e) \times 100 \\
K & =W e / T^{3} \times 100
\end{aligned}
$$

Length at first maturity was described by the classic "ogive" function:

$$
P=1 / 1+e^{-r(L-L 50)}
$$

Where $\mathrm{P}$ is the proportion of mature fish at size $\mathrm{L}$, $L_{50}$ is the length at which $50 \%$ of specimens were mature and $r$ is the curvature parameter (King, 1995). Ogive parameters were calculated using non linear least squares estimation.

Sagitta of 251 fish were collected and stored dry in labelled small tubes. Otoliths were read as whole under water by reflected light against a black background at a magnification of $10 \times$. In case otoliths are thick and opaque, it was included in Implex resin and sectioned transversely through the 'core' using an Isomet lowspeed saw (McKurdy et al., 2002). Thin sections (about $0.6 \mathrm{~mm}$ ) were polished with aluminum oxide powder and observed under transmitted light at a magnification of $10 \times$. The otoliths and the sections were analyzed by three readers and only the agreed readings were accepted.

The individual age was estimated by counting growth increments, one opaque zone with one translucent zone was considered as annual growth (reflected light) (Figure 2). The first translucent ring near

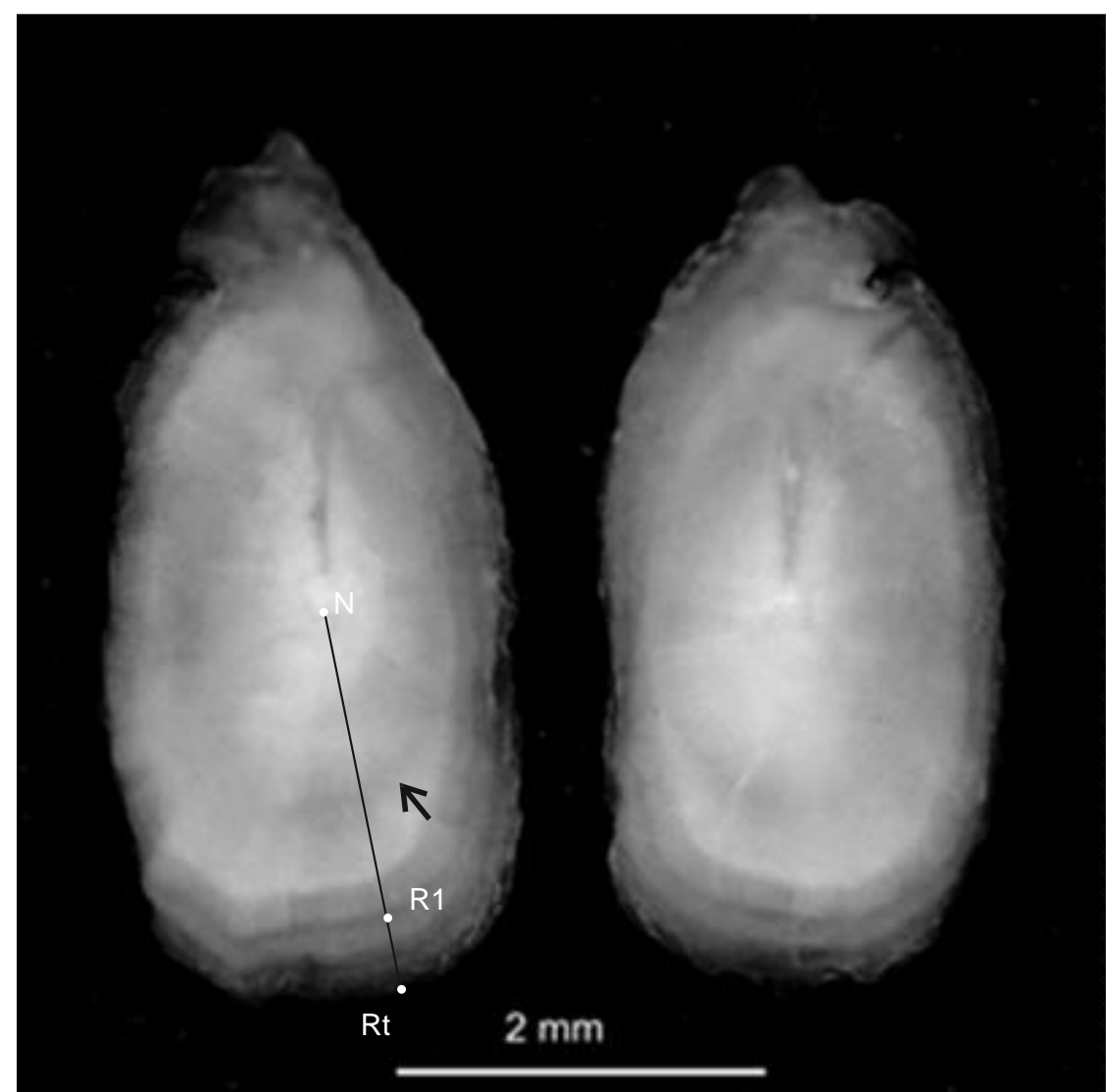

Figure 2. Sagittal otolith of B. belone from off Tunisia (Central Mediterranean Sea). N: nucleus, Rt: total otolith Radius, R1: distance to the edge of transparent ring indicating first year, black arrow: larval ring 
the nucleus was considered as larval and not counted for age estimation (Wright et al., 2002). Yearly increments are counted considering translucent zones. To assign a fish to an age group, one entire year is considered for the count when the border of the otolith is translucent. Also, Total Radius (TR), the distance between the nucleus and the edge of the otolith and the distance from the nucleus to the edge of each transparent ring (Ri) were measured. The relationship between TL and TR was determined as the classical linear regression $T L=a \times$ $T R+b$, and the result of linear regression was adopted for back-calculation (Francis, 1990). Differences between sexes were tested by the analysis of covariance (ANCOVA). The von Bertallanffy equation (VBGF) was established from the back-calculated length at age using parameters of the linear relationship between $T L$ and TR. The growth equation used was in the form of:

$$
L t=L_{\infty}\left(1-e^{-K(t-t o)}\right)
$$

Where $\mathrm{Lt}=$ the total length at age $\mathrm{t}$ (years), $\mathrm{L}_{\infty}=$ the theoretical asymptotic total length, $k=$ constant expressing the rate of change in length increments with respect $t_{0}$ and $t, t_{0}=$ the hypothetical age at length zero.

Parameters of the von Bertalanffy growth equation were estimated by the non linear approach as implemented in Fisat II (Gayanilo et al., 2006).

Differences in the growth parameters by sexes were tested by the analysis of the residual sum of squares (ARSS) (Chen et al., 1992), in which F-statistic was calculated as:

$$
F=\frac{\operatorname{RSS} p-\mathrm{RSS} s / \mathrm{DF} \operatorname{RSS} p-\mathrm{DF} \operatorname{RSS} s}{\operatorname{RSS} s / \mathrm{DF} \operatorname{RSS} s}
$$

Where RSSp is RSS of each VBGF fitted by pooled growth data; RSSs is the sum of the RSS of each VBGF fitted to growth data for each individual sample.
For the sake of comparison, the index of overall growth performance $\varphi^{\prime}$ proposed by Pauly and Munro (1984) was calculated as:

$$
\varphi^{\prime}=2 \log 10 L_{\infty}+\log 10 \mathrm{~K}
$$

Statistical analyses were performed using SPSS (Version 20). Differences in the length frequency distribution between sexes were checked by nonparametric test (Kolmogorov-Smirnov, K-S, test). The analysis of one-way ANOVA, followed by Tukey's post hoc test (Zar, 1996), was used to confirm significant differences in monthly values of all indices (GSI, HSI, and K). The level of significance was 0.05 .

\section{Results}

\section{Population Structure}

Among the 453 examined garfish, 284 were females (70.3\%) and 120 were males (29.7\%). The overall sex ratio estimated as females out males of 2.36 $\div 1$ differs significantly from $1 \div 1\left(\chi^{2}=16.47, P<0.05\right)$ skewed towards females. Variations in the proportions of sexes related to sizes showed significant dominance of females compared to males in all size classes $(P<0.05)$ (a small number of examined specimens of total lengths less than $25 \mathrm{~cm}$ and beyond $50 \mathrm{~cm}$ can be excepted) (Figure 3). Significant differences of sex proportions in favor of females were found throughout all months except in July $\left(\chi^{2}=0.73, P>0.05\right)$ (Figure 4).

The total length of examined garfishes ranged from 24.2 to $55 \mathrm{~cm}$ with an average of $40.2 \pm 5.9 \mathrm{~cm}$ for females and from 25.8 to $52.5 \mathrm{~cm}$ with an average of $40.0 \pm 4.5 \mathrm{~cm}$ for males. The length frequency distribution showed an unimodal distribution for females and males. The K-S test revealed significant differences in size frequency distribution between sexes

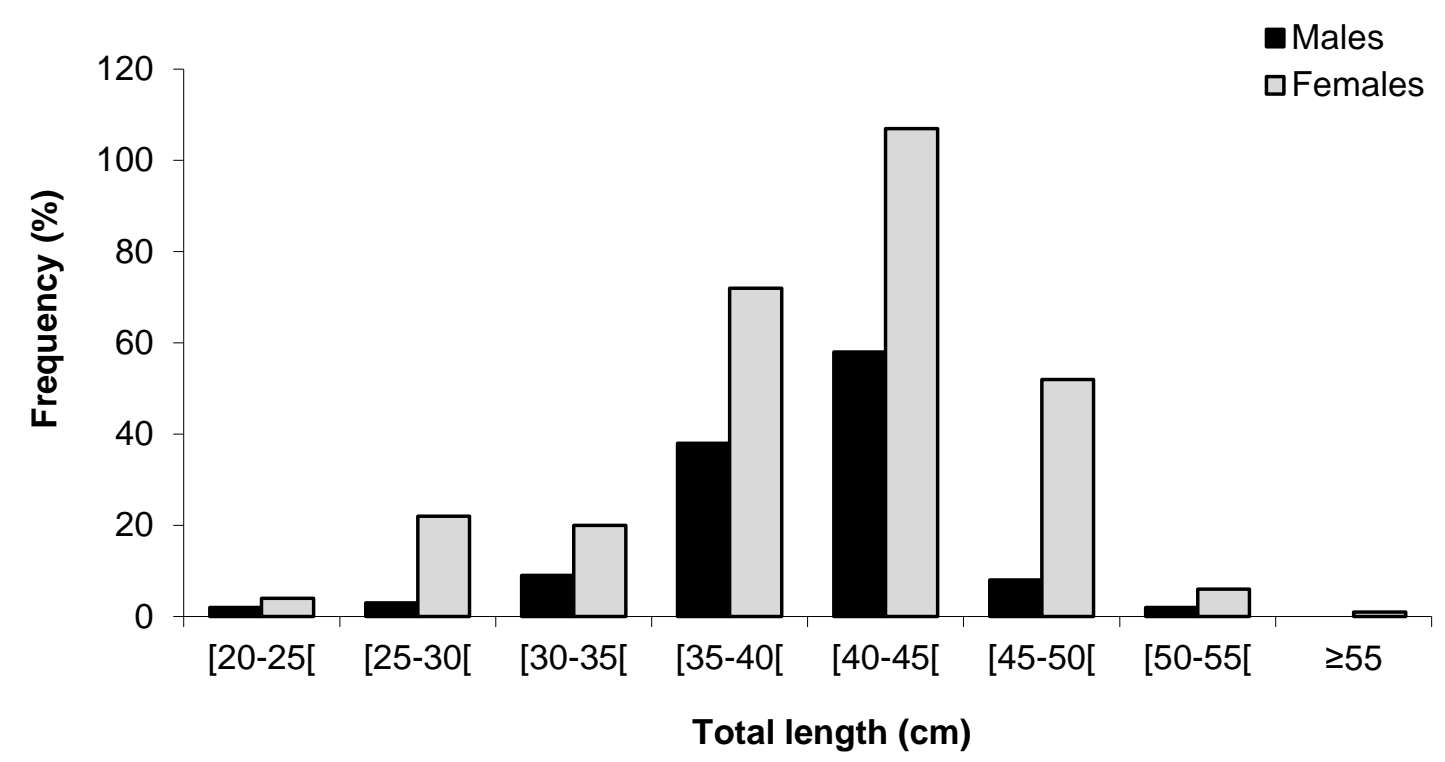

Figure 3. Length frequency distribution of females and males Belone belone from off Tunisia (Central Mediterranean Sea) 


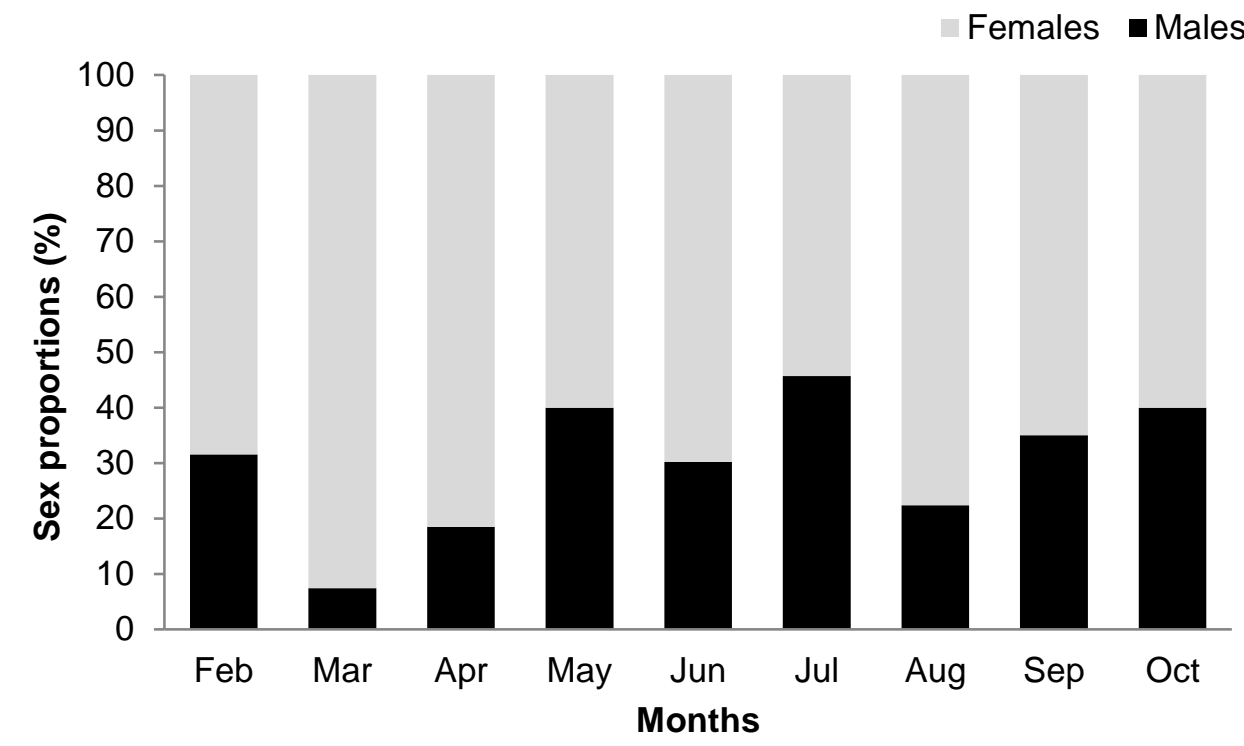

Figure 4. Monthly variations in females and males proportions of Belone belone from off Tunisia (Central Mediterranean Sea)
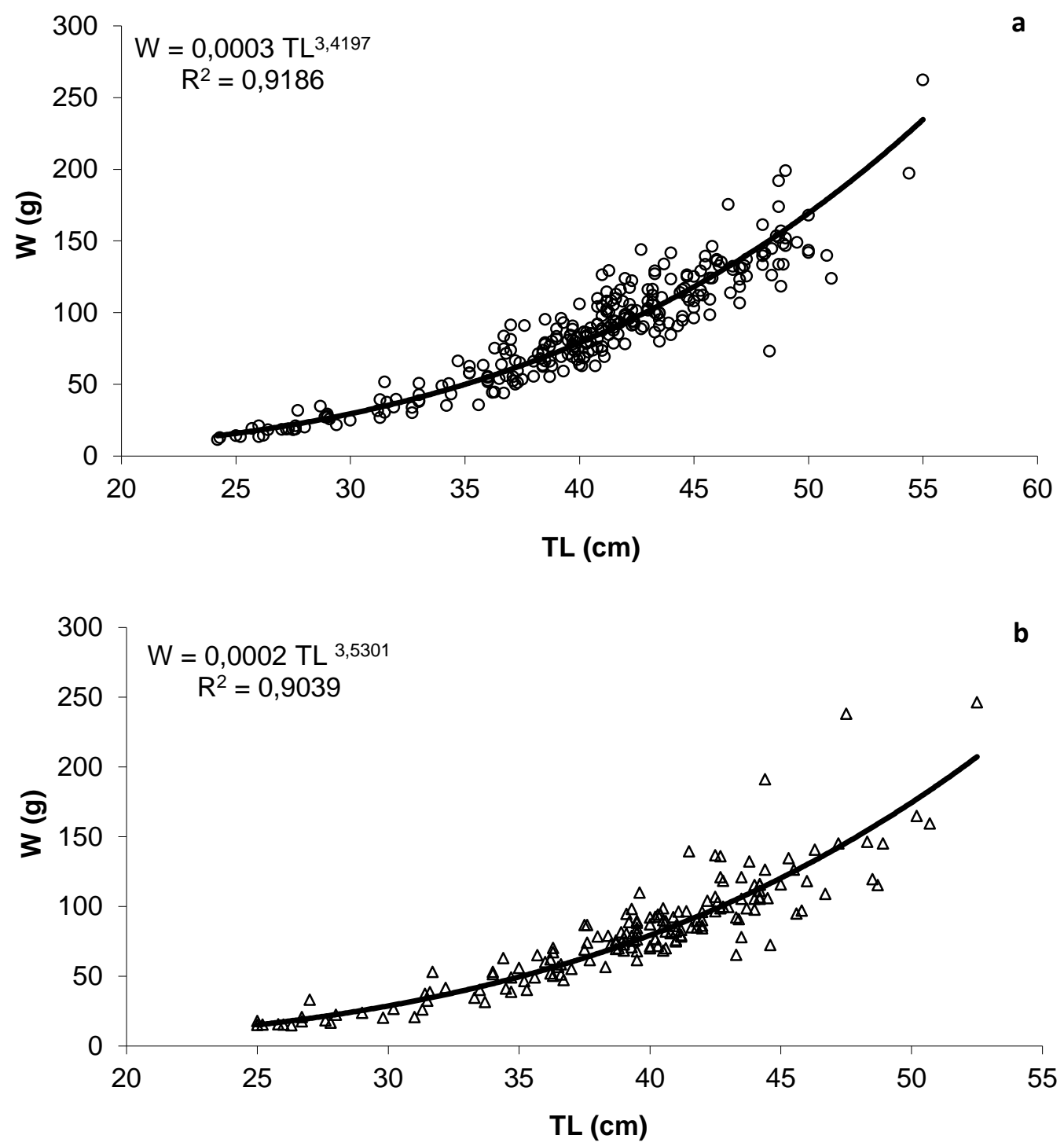

Figure 5. Length-weight relationships of $B$. belone from off Tunisia (Central Mediterranean sea)- a. Females, b. Males 
$(P<0.05)$. The catch was composed mainly of specimens between 40 and $45 \mathrm{~cm}$ of the total length (Figure 3). The total weight ranged from 11.4 to $262.2 \mathrm{~g}$ with a mean of $88.2 \pm 39.1 \mathrm{~g}$ for females and from 14.9 to $246.2 \mathrm{~g}$ with a mean of $81.2 \pm 39 \mathrm{~g}$ for males. Length-weight relationships calculated as $W=0.0003 L^{3.419}\left(R^{2}=0.91\right)$ and $W=0.0002 L^{3.530}\left(R^{2}=0.90\right)$ showing positive allometric growth for females and males respectively (Figures 5a-b). Significant differences were recorded between sexes in the length-weight relationships using the covariance analysis (Table 1 ).

\section{Age and Growth}

Otoliths reading of garfish $B$. belone showed wellvisible altering opaque and translucent zones (Figure 2). Of the 251 otoliths examined, only $9 \%$ were unreadable. Total otolith radius and total length relationships were linear (Figures $6 a-b$ ). Females aged from 1 to 4 years for a total length from 24.2 to $55 \mathrm{~cm}$. Males were between 1 to 5 years ranging from 25.8 to $52.5 \mathrm{~cm}$ total length. An age-length key was constructed and the age group 2 was the dominant (56\%) (Table 2). Back-calculated mean total length-at-ages and estimated growth parameters using VBGF were given in Table 3 and Figure 7. The Chen's test showed no significant difference by sexes in growth pattern (Table 4). Moreover, no significant difference was found between sexes in the slopes of the linear relationship slopes between TL and TR using covariance analysis (Table 5).

\section{Spawning Period}

The monthly distribution of maturity stages for females and males showed that immature specimens were observed from May to October. Ripe gonads were found from February to June with maximum percentages observed during March and April for females (Figure 8). Monthly mean values of gonadosomatic index (GSI) followed that of gonads maturity stages. The GSI increased in February and reached the highest levels in March and April for females. Then a sharp decline occurred in May and June for females. Curves of GSI are unimodal for both sexes indicating that

Table 1. Belone belone ANCOVA of TL vs. TW relationships. SS: sum of squares; d.f.: degree of freedom; MS: mean squares; F: statistics compared with fish distribution; $P$ : P-value

\begin{tabular}{lccccc}
\hline & SS & df & MS & $F$ & $P$ \\
\hline Test for heterogenity of slopes & & & & & \\
Common Residual & 2.356927 & 446 & 0.005285 & & \\
Sum Residuals & 2.351204 & 445 & 0.005284 & & \\
Difference & 0.005724 & 1 & 0.005724 & 1.083285 & 0.298529 \\
Test for differences between intercepts & & & & & \\
Total Residual & 1565.718 & 447 & 3.502726 & & \\
Common Residual & 2.356927 & 446 & 0.005285 & & \\
Difference & 1563.361 & 1 & 1563.361 & 295834 & $<0.001$ \\
\hline
\end{tabular}

Table 2. Length frequency distribution and component age groups of total sampled garfish B. belone from off Tunisia (Central Mediterranean Sea). - : none caught

\begin{tabular}{|c|c|c|c|c|c|c|c|}
\hline \multirow[b]{2}{*}{ Total length $(\mathrm{cm})$} & \multicolumn{7}{|c|}{ Age groups (years) } \\
\hline & 0 & 1 & 2 & 3 & 4 & 5 & Total \\
\hline $20-24.9$ & 1 & 2 & - & - & - & - & 3 \\
\hline $25-29.9$ & - & 12 & 9 & 1 & - & - & 22 \\
\hline $30-34.9$ & - & 4 & 17 & 2 & - & - & 23 \\
\hline $35-39.9$ & - & 1 & 42 & 18 & 4 & - & 65 \\
\hline $40-44.9$ & - & 1 & 40 & 34 & 2 & - & 77 \\
\hline $45-49.9$ & - & - & 18 & 9 & 4 & - & 31 \\
\hline $50-54.9$ & - & - & 1 & - & 3 & 1 & 5 \\
\hline $55-59.6$ & - & - & 1 & - & - & - & 1 \\
\hline Number of fish & 1 & 20 & 128 & 64 & 13 & 1 & 227 \\
\hline Frequency \% & 0.44 & 8.81 & 56.39 & 28.19 & 5.73 & 0.44 & \\
\hline
\end{tabular}

Table 3. The von Bertalanffy $B$. belone growth parameters. $L_{\infty}$ : asymptotic total length; $K$ : growth curvature parameter; $t_{0}$ : the hypothetical age at length zero; $\varphi^{\prime}$ : growth performance index

\begin{tabular}{lcc}
\hline Parameters & Females & Males \\
\hline $\mathrm{L}_{\infty}$ & 48.48 & 44.70 \\
$\mathrm{~K}$ & 0.57 & 0.67 \\
to & -1 & -1 \\
$\varphi^{\prime}$ & 3.12 & 3.12 \\
\hline
\end{tabular}


Table 4. Sex comparison of growth modeled by VBGF by means of RSS of B. belone. RSSp: RSS of each VBGF fitted by pooled growth data; RSSs: sum of the RSS of each VBGF fitted to growth data for each individual sample

\begin{tabular}{lccccc}
\hline RSS $_{\text {pooled }}$ & 3879.54 & $\mathrm{RSS}_{\text {sample }}$ & 3736.09 & $\mathrm{~F}$ & 2.35 \\
$\mathrm{DF}$ pooled & 187 & $\mathrm{DF}_{\text {sample }}$ & 184 & $P$ & 0.07 \\
\hline
\end{tabular}

Table 5. Belone belone ANCOVA of TL vs. TR relationships. SS: sum of squares; d.f.: degree of freedom; MS: mean squares; F: statistics compared with fish distribution; $P$ : $P$-value

\begin{tabular}{lccccc}
\hline & SS & df & MS & $F$ & $P$ \\
\hline Test for heterogenity of slopes & & & & & \\
Common Residual & 0.25586 & 154 & 0.001661 & & \\
Sum Residuals & 0.253956 & 153 & 0.00166 & & \\
Difference & 0.001904 & 1 & 0.001904 & 1.147078 & 0.285848 \\
Test for differences between intercepts & & & & & \\
Total Residual & 7.438728 & 155 & 0.047992 & & \\
Common Residual & 0.25586 & 154 & 0.001661 & & \\
Difference & 7.182868 & 1 & 7.182868 & 4323.304 & $<0.001$ \\
\hline
\end{tabular}
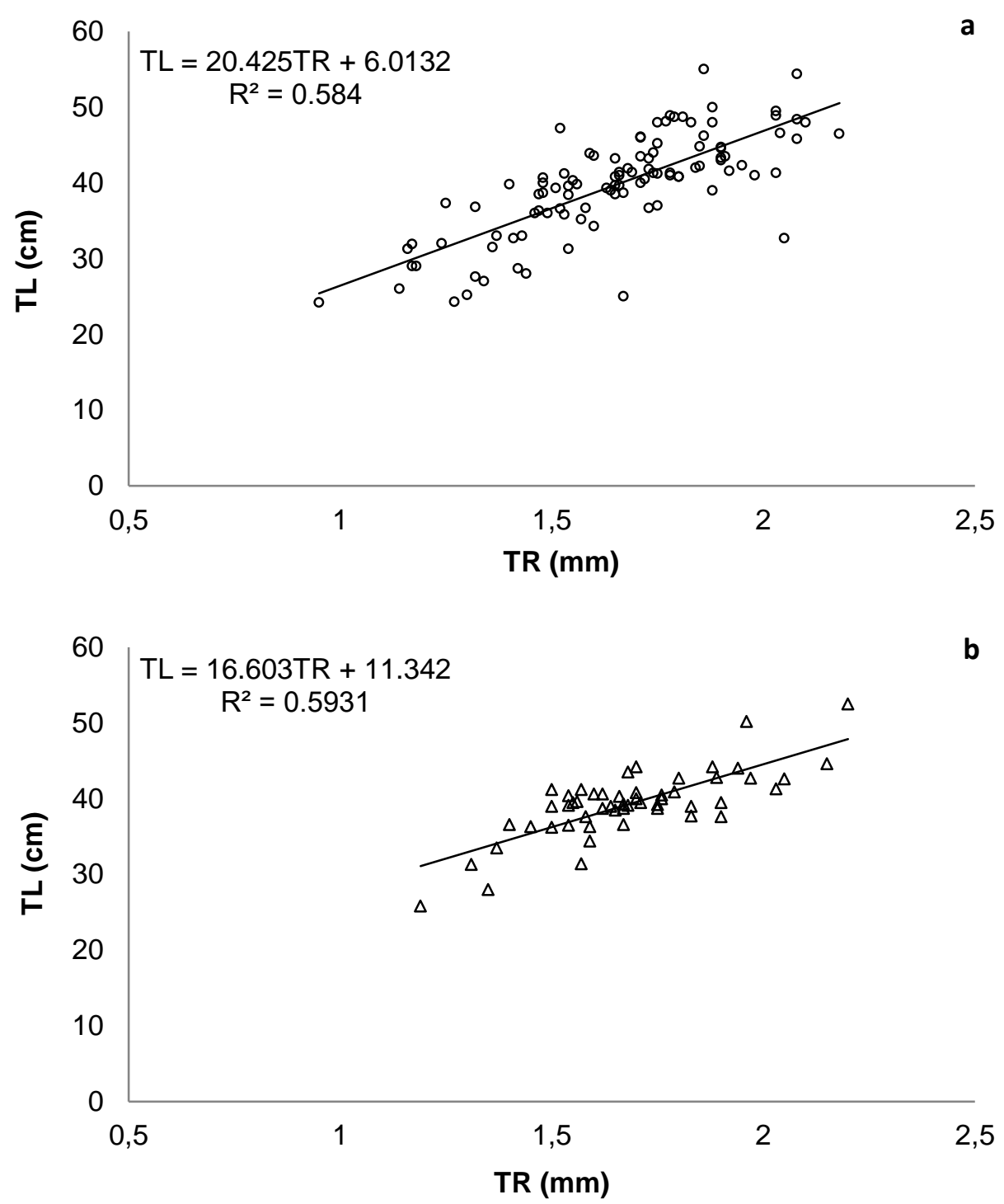

Figure 6. Total otolith radius (TR) vs. total body length (TL) relationships of $B$. belone from off Tunisia (Central Mediterranean Sea)- a. Females, b. Males 


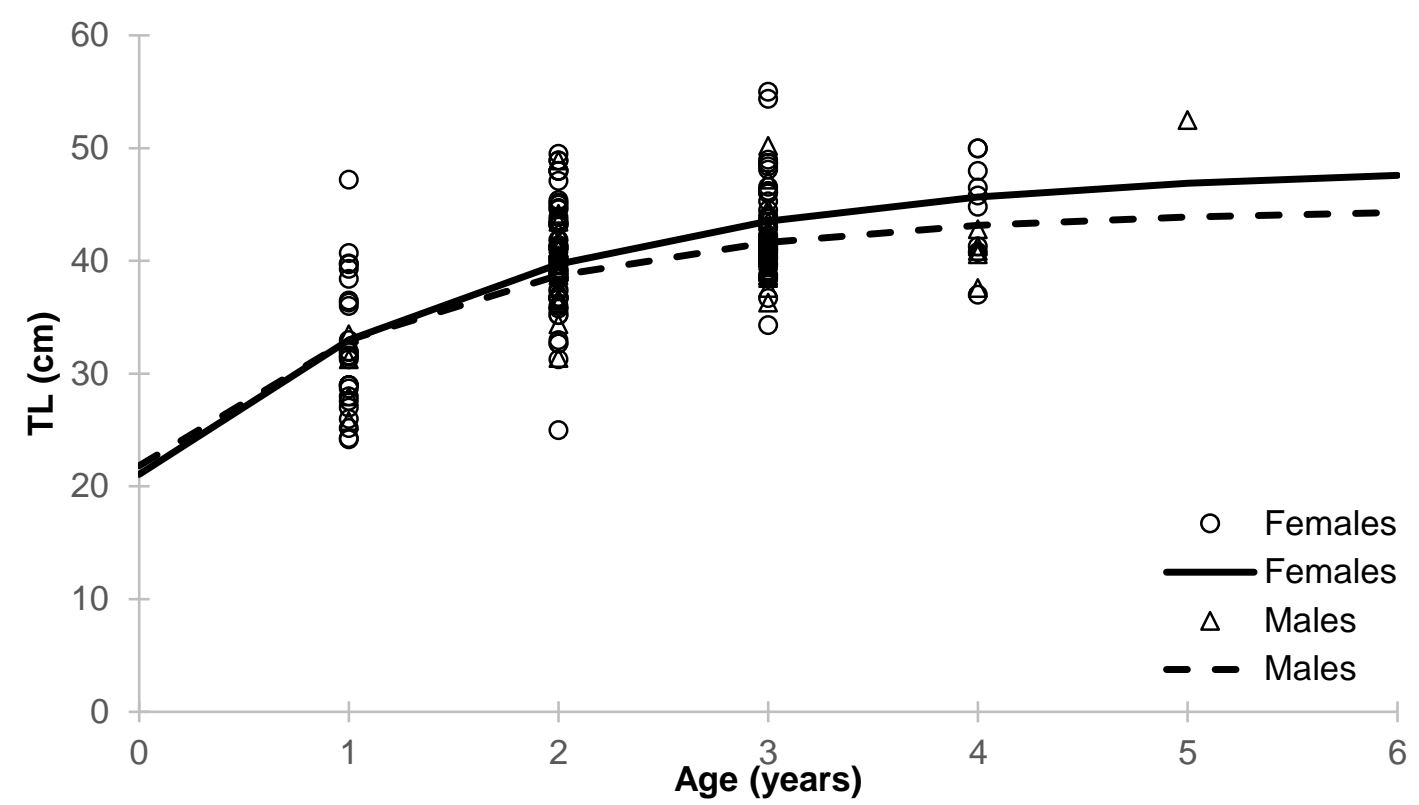

Figure 7. Back calculated length at age and von Bertallanffy growth curve (VBGF) by sex of garfish B. belone from off Tunsia (Central Mediterranean Sea)
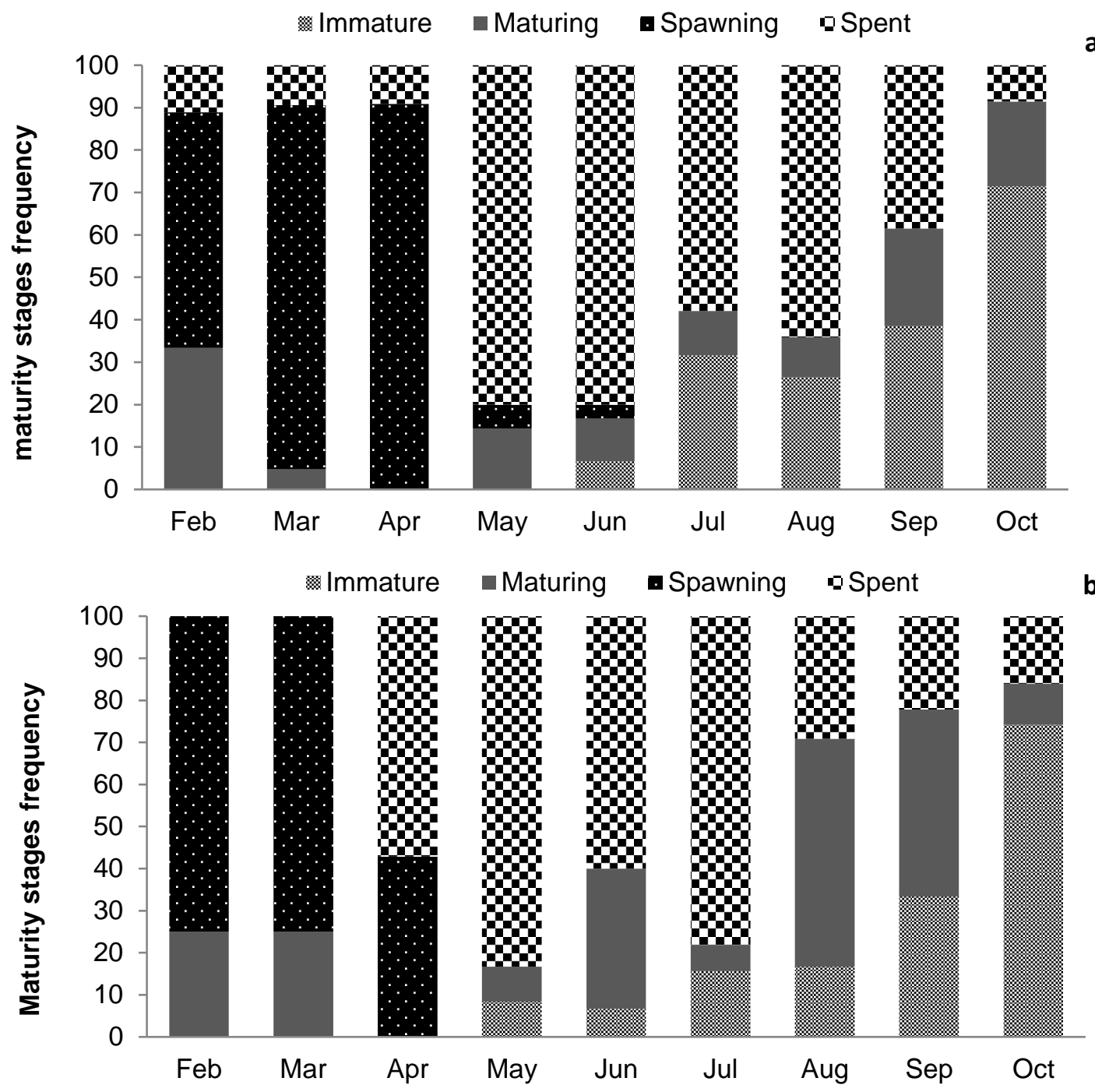

Figure 8. Monthly variations of gonad maturity stages of Belone belone from Tunisia (Central Mediterranean Sea)- a. females, b. Males 
B. belone reproduced once a year (Figure 9a). The GSI mean values were significantly higher for females than for males $(F=50.94, P<0.01)$.

The hepatosomatic index (HSI) showed significant monthly changes for both females and males $(F=2.3$, $\mathrm{P}<0.05)$. Variations in the HSI follow a slightly similar pattern to that of GSI with higher values for females than for males. Maximum values were observed in March for both sexes (Figure 9b).

Values of the condition factor $(K)$ vary significantly according to months for females and males ( $F=3.88$; $P<0.01)$. Maximum values of the condition index were recorded in October which is outside the reproduction period for both sexes. Significant variation was also found between sexes $(F=7.73 ; P<0.01)$ (Figure $9 c)$.

\section{Length at First Maturity}

Length at first maturity ( $\left.L 5_{0}\right)$ of females was at an average total length of $37.3 \pm 0.10 \mathrm{~cm}(r=0.76 \pm 0.05)$ and males at total length of $37.2 \pm 0.40 \mathrm{~cm}(r=0.47 \pm$ 0.07 ) (Figure 10). Females and males B. Belone from Tunisian coast reached, therefore, their first maturity between 1 and 2 years (inverse VBGF).

\section{Discussion}

Earlier findings showed that the size structures of garfish Belone Belone from the Atlantic differs from those recorded in the Mediterranean Sea. While, relatively larger total lengths specimens were found in

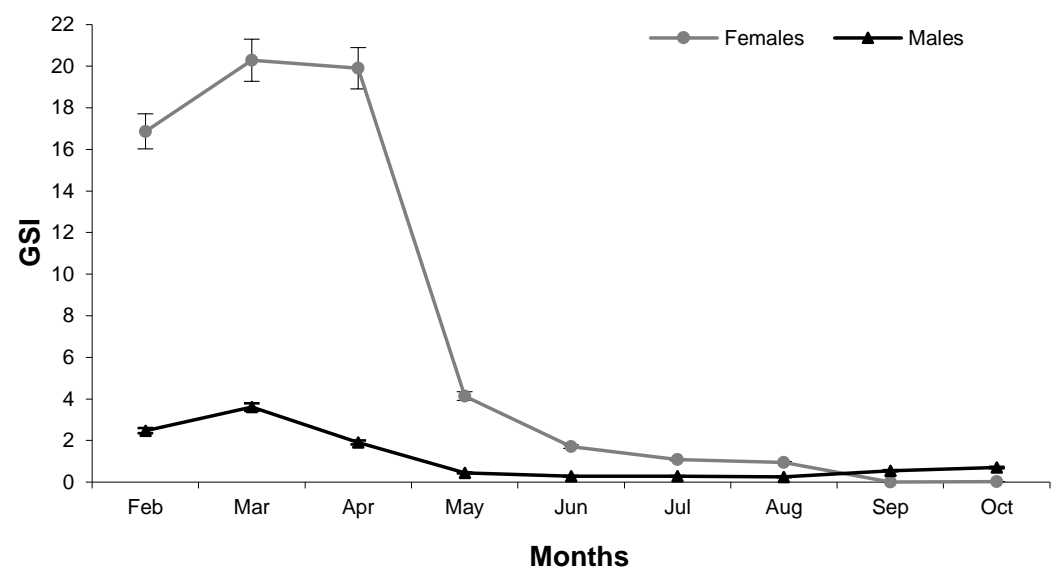

a
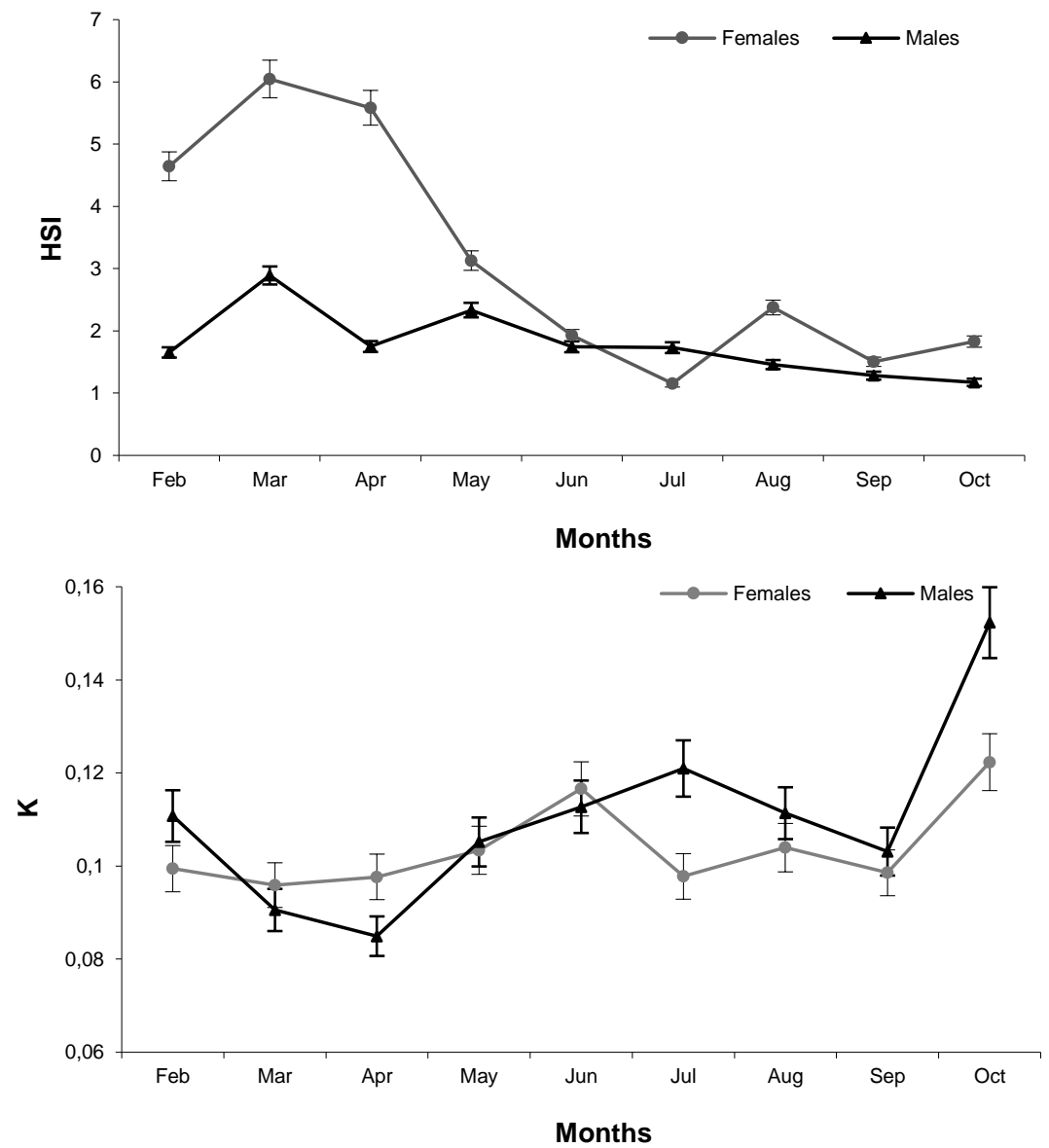

b

C

Figure 9. a Monthly gonado-somatic index (GSI), b. Hepato somatic index (HSI) and c. condition factor (K) for females and males of Belone belone from Tunisia (Central Mediterranean Sea) 

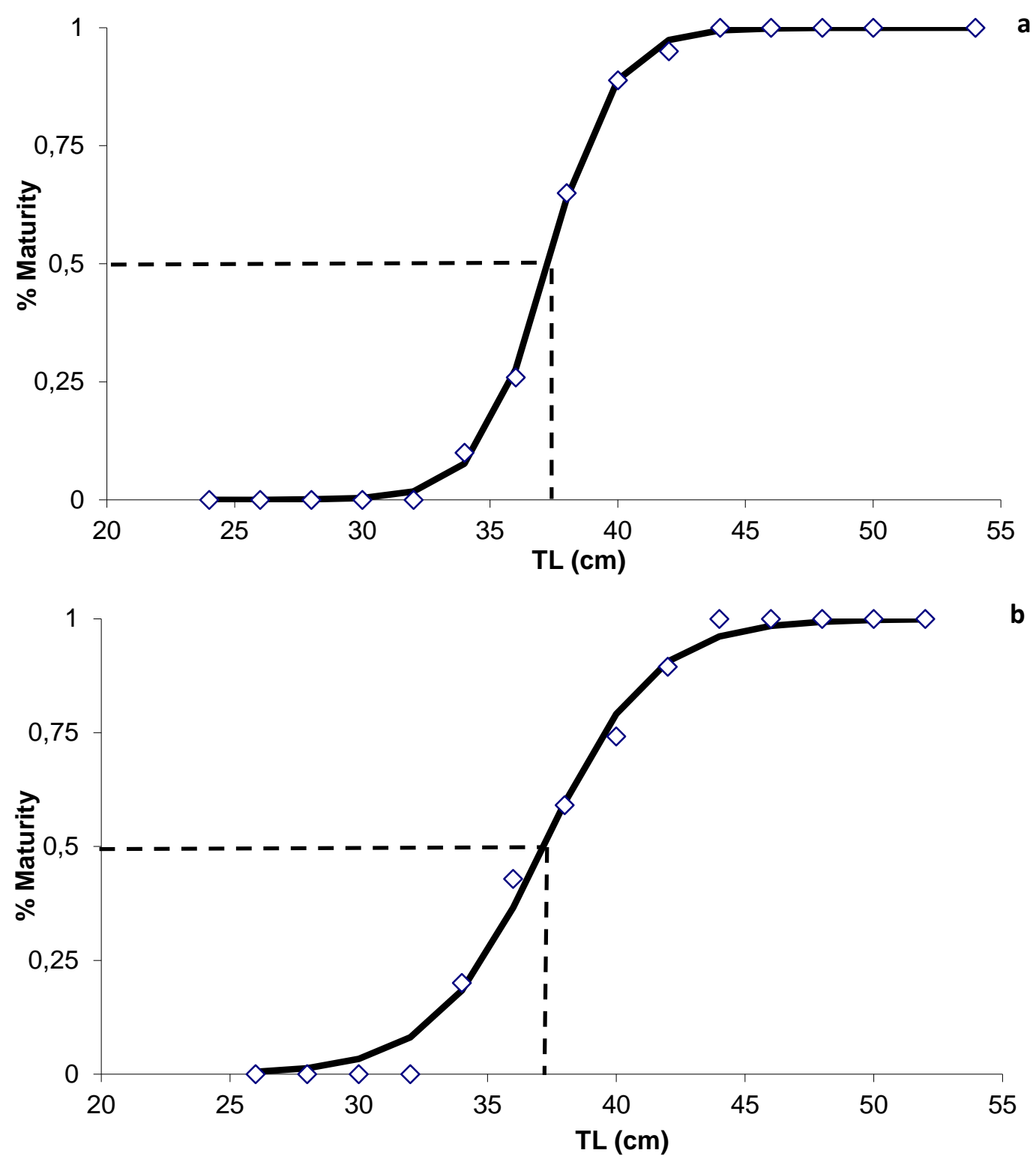

Figure 10. Length at first maturity of B. belone from off Tunisia (Central Mediterranean Sea). a. Females, b. Males

the North East Atlantic by Dorman (1991) $(55 \mathrm{~cm}-85$ $\mathrm{cm})$ and Borges et al. (2003) $(25.3-91.6 \mathrm{~cm})$, the range of sampled specimens of garfish $(24.2-55 \mathrm{~cm})$ is quite similar to those reported by Bedoui et al. (2002) (24 - 57 $\mathrm{cm})$ then by Fehri-Bedoui and Gharbi (2004) (23.7 - 52 $\mathrm{cm}$ ) from Tunisia. Similar size range (26 $-54.6 \mathrm{~cm}$ of Fork Length) was also reported by Uçkun (2004) in the Aegean Sea. On the other hand, the maximum total length of $93.3 \mathrm{~cm}$, recorded by Acarli et al. (2018) in the Aegean Sea, seems to be doubtful as a possible confusion could occur with Tylosurus imperialis which is reported to be sympatric of Belone belone in this area (Türker Çakır \& Zengin, 2013). Indeed, the fish picture given by Acarli et al., (2018) (Figure 2, page 386) fits perfectly with $T$. imperialis which is characterized by small black lateral keel garnishing the caudal peduncle deeply forked with a lower lobe longer than the upper (Collette \& Parin, 1970). The largest $B$. belone were reported from the Adriatic Sea $(20.8-75.4 \mathrm{~cm})$ (Zorica \&
Čikeš Keč, 2011, Zorica et al. 2011, Zorica \& Čikeš Keč, 2013). In the Adriatic Sea garfishes were caught mainly by seine net (stretched mesh $10-30 \mathrm{~mm}$ ) but also by catch species in purse seine fisheries (Zorica \& Čikeš Keč, 2013).

The difference in the size structure of garfishes among localities can be related to different exploitation rates of fish stock and/or to variability of environmental factors, mainly the temperature and prey availabilities. Fishing has the most prominent effect on the size structure of the exploited stocks. It represents sizeselective removal of larger individuals that can truncate the size structure of a fish population (Tu et al., 2018). Sparre and Venema (1998) suggested that the complete length ranges are not always under full exploitation for fishing gear selectivity. It appeared that, most fishing gears; ie trawl gears, are selective for larger sizes while some gillnets are selective for a certain length range only, thus excluding capture of very small and large fish. 
In principle, a seine net should work like trawl as far as selection is concerned. However, it is more difficult to deal with the seine because this type of gear is used to catch schooling species.

Similarly, differences in the sex ratio patterns of garfish populations among geographical areas can be noted. A sex ratio in favor of females seems to be common for $B$. belone as reported in the North East Atlantic and in the Mediterranean Sea (Dorman, 1989; Bedoui et al., 2002; Fehri-Bedoui \& Gharbi 2004; Uçkun et al., 2004 and present study). However, a female dominance was reported in $B$. belone only in size classes $(>80 \mathrm{~cm}$ ) from Swedish waters and in length classes (>39 $\mathrm{cm}$ ) from the Adriatic Sea respectively (Dorman, 1991; Zorica et al., 2011). Variations in the sex ratio of garfishes may be related to sexual dimorphism in size, gear selectivity, sampling strategies and spawning migrations (Zorica et al. 2011; Bilgin et al., 2014 b). Belone belone seem to have migratory behavior from offshore towards coasts for spawning in the spring season. This spawning migration could be confirmed by the dominance of females in coastal areas and the

Table 6. Spawning time and size at fist maturity of garfishes from different locations

\begin{tabular}{|c|c|c|c|c|}
\hline \multirow{2}{*}{ Author } & \multirow{2}{*}{ Locality } & \multirow{2}{*}{ Spawning season } & \multicolumn{2}{|c|}{ Length at maturity $\mathrm{L}_{50}(\mathrm{~cm})$} \\
\hline & & & Females & Males \\
\hline Yüce (1970) & Mediterranean (Aegean Sea) & April-August & - & - \\
\hline Uçkun et al. (2004) & Mediterranean (Aegean Sea) & April-August & - & - \\
\hline Zorica et al. (2011) & Mediterranean (Adriatic Sea) & January-May & 31.5 & 28 \\
\hline Collette \& parin (1986) & Mediterranean (Spain) & February-May & - & - \\
\hline $\begin{array}{l}\text { Whitehead et al. (1986), } \\
\text { Bauchot (1987) }\end{array}$ & Mediterranean (Algeria) & Februray-May & - & - \\
\hline Bedoui et al. (2002) & Mediterranean (Tunisia) & March-May & 36.8 & 36.3 \\
\hline Present study & Mediterranean (Tunisia) & February-June & 37.3 & 37.2 \\
\hline Whitehead et al. (1986) & Black Sea & April-September & - & - \\
\hline $\begin{array}{l}\text { Collette \& parin (1986), } \\
\text { Bauchot (1987) }\end{array}$ & Black Sea & April-September & - & - \\
\hline Samsun et al. (2006) & Black Sea & May-September & 38.8 & - \\
\hline Bilgin et al. (2014 b) & Black Sea & May-September & 34.4 & 33.3 \\
\hline Rosenthal \& Fonds (1973) & Atlantic (Germany) & May-June & - & - \\
\hline Whitehead et al. (1986) & Atlantic (British Isles) & May-June & - & - \\
\hline Dorman (1989) & Atlantic (South Ireland) & June & - & - \\
\hline Dorman (1991) & Atlantic (Swedish waters) & May-June & - & - \\
\hline Dorman (1991) & Atlantic (Baltic Sea) & August-September & - & - \\
\hline
\end{tabular}

Table 7. Summary of the Length weight slope regression line $(b)$, Von Bertalanffy growth parameters $\left(L_{\infty}\right.$ in $\left.c m, k, t_{0}\right)$ and growth performance $\left(\varphi^{\prime}\right)$ of garfishes from different geographic regions. ${ }^{*}$. Size studied measure fork length. F, female; $M$, males

\begin{tabular}{|c|c|c|c|c|c|c|c|}
\hline Author & Locality & Sex & $\mathrm{b}$ & $\mathrm{L}_{\infty}(\mathrm{cm})$ & $\mathrm{k}$ & $t_{0}$ & $\varphi^{\prime}$ \\
\hline Samsun (1996) & Black Sea & $\mathrm{F}+\mathrm{M}$ & 3.17 & 56.01 & 0.32 & -1.86 & 3.01 \\
\hline Samsun et al. (1995) & & $\mathrm{F}+\mathrm{M}$ & 3.22 & 62.8 & 0.19 & -3.38 & 2.88 \\
\hline Samsun et al. (2006) & & $\mathrm{F}+\mathrm{M}$ & 3.13 & 74.6 & 0.13 & -3.67 & 2.85 \\
\hline Polat et al. (2009)* & & $\mathrm{F}+\mathrm{M}$ & 3.24 & 79.1 & 0.19 & -1.42 & 3.09 \\
\hline \multirow[t]{2}{*}{ Kalayci \& Yeşilçiçek (2012) } & & $\mathrm{F}$ & - & 41.6 & 0.72 & -0.51 & 3.09 \\
\hline & & $M$ & & 37.48 & 0.75 & -0.61 & 3.02 \\
\hline \multirow[t]{3}{*}{ Bilgin et al. (2014 a) } & & $\mathrm{F}$ & 3.18 & 81.6 & 0.12 & -2.24 & 2.92 \\
\hline & & $M$ & 3.09 & 71.9 & 0.15 & -2.12 & 2.89 \\
\hline & & $\mathrm{F}+\mathrm{M}$ & 3.13 & 84.6 & 0.11 & -2.34 & 2.91 \\
\hline Ceyhan et al., (2019) & & $\mathrm{F}+\mathrm{M}$ & 3.04 & 55.74 & 0.28 & -1.68 & 2.93 \\
\hline \multirow[t]{3}{*}{ Uçkun et al. (2004)* } & Aegen Sea & $\mathrm{F}$ & 3.46 & 62.24 & 0.24 & -1.42 & 2.97 \\
\hline & & $M$ & 3.07 & 54.32 & 0.33 & -1.25 & 2.99 \\
\hline & & $\mathrm{F}+\mathrm{M}$ & 3.40 & 62.71 & 0.23 & -1.56 & 2.97 \\
\hline \multirow[t]{3}{*}{ Zorica \& Čikeš Keč (2013) } & Adriatic Sea & $\mathrm{F}$ & 3.47 & 89.5 & 0.16 & -0.06 & 3.12 \\
\hline & & $M$ & 3.63 & 85.2 & 0.15 & -0.32 & 3.06 \\
\hline & & $\mathrm{F}+\mathrm{M}$ & 3.48 & 90.3 & 0.15 & -0.10 & 3.11 \\
\hline \multirow[t]{3}{*}{ Sinovčvić et al. (2004) } & Adriatic Sea & $\mathrm{F}$ & 3.16 & & & & \\
\hline & & $M$ & 2.71 & & & & \\
\hline & & $\mathrm{F}+\mathrm{M}$ & 3.01 & & & & \\
\hline \multirow[t]{3}{*}{ Fehri-Bedoui \& Gharbi (2004) } & Mediterranean Sea & $\mathrm{F}+\mathrm{M}$ & 3.48 & 61.4 & 0.10 & -2.88 & 2.61 \\
\hline & & $\mathrm{F}$ & 3.55 & & & & \\
\hline & & $\mathrm{M}$ & 3.28 & & & & \\
\hline \multirow[t]{2}{*}{ Present study } & Mediterranean Sea & $\mathrm{F}$ & 3.41 & 48.48 & 0.57 & -1 & 3.12 \\
\hline & & $\mathrm{M}$ & 3.53 & 44.7 & 0.67 & -1 & 3.12 \\
\hline
\end{tabular}


absence of landing specimens in late autumn and early winter despite our sampling efforts during 6 years. Migration of $B$. belone to coastal area for spawning then leaving coasts and getting back to the deep open sea waters after spawning have been previously reported in the North East Atlantic. Rosenthal \& Fonds (1973) suggested that $B$. belone enters the Wadden Sea, North Sea in April, to spawn in May and June and disappear in October indicating migration at winter to greater depth (lower light intensity) in the offshore avoiding water temperatures below $6{ }^{\circ} \mathrm{C}$ and rough weather conditions in the upper water layers. Moreover, Dorman (1989) mentioned that garfish migrate into the coastal waters of the British Isles and northern Europe every summer for spawning. Belone belone regularly migrates in spring for reproduction (Dalgaard et al., 2006), through Swedish coastal waters and migration continues into the southern coast of Bothnia then returns to the offshore of eastern North Atlantic Ocean in late summer to autumn (Dorman, 1991; Dalgaard et al., 2006). Similarly, $B$. belone from the Adriatic Sea has migratory patterns during the winter and spring spawning period when specimens move into coastal regions and become more exposed to fishery (Zorica et al., 2011).

Our finding showed that garfish $B$. belone from Central Mediterranean spawn in late winter-early spring. Differences in the period and duration of spawning period of garfishes were also recorded among geographical areas. Spawning time showed more similarities in the Mediterranean compared to other localities (Table 6). It seems that reproduction occurs in spring-summer in the Atlantic, in winter-spring in the western Mediterranean and in the Adriatic Sea and in summer in the Aegean Sea and Black Sea. Changes in the spawning season of garfishes can be due to differences in environmental factors such as temperature and salinity (Zorica et al., 2011; Bilgin et al., 2014 b). Temperature is one of the most important factors affecting the reproductive activity and the embryonic and larval development and growth of fish (Pankhurst \& Munday, 2011). Moreover, it was suggested that data differences in spawning season of fish species between geographical areas could be related to food accessibility.

Concerning size at sexual maturity, B. belone from the present study showed a slightly higher total length at first maturity than other localities (Table 6). Differences in the length at sexual maturity could be related to the sensibility of the garfish species to environmental changes, reproductive parameters, sample size and/or fishing pressure level and overexploitation probably as a compensatory response (Morales-Nin et al. 2002; Engelhard \& Heino, 2004; Dominguez-petit et al. 2008; Zorica et al., 2011).

Our finding showed that $B$. belone is relatively slow growing and short living species. This growth rate is closest to the Adriatic Sea garfish (Zorica \& Čikeš Keč, 2013). The growth performance index $\left(\varphi^{\prime}\right)$ calculated from growth parameters reported by Fehri-Bedoui \& Gharbi (2004) of Tunisia is the lowest value reported in garfishes (Table 7). Differences could be related to ageing methods used by these authors (Bhattacharya). Results of Fehri-Bedoui \& Gharbi (2004) showed that professional fishing catch of $B$. belone from Tunisia mainly affects mature individuals larger than $37.5 \mathrm{~cm}$ of size and older than 5 years of age.

In conclusion, this study provides useful information enhancing and updating knowledge on some biological aspects of the Mediterranean garfish, Belone belone that may be helpfull for the management and sustainability of marine species exploitation.

\section{Ethical Statement}

No ethical statement declared.

\section{Funding Information}

No financial support was used for this study.

\section{Author Contribution}

M.C.: Conceptualization, data collection and analysis, Writing -review and editing; L.B.: data analysis, review and editing; S.G.: laboratory techniques for the growth age reading and analysis, review and editing; V.G.: data and statistical analysis and L.N.: Supervision, Writing - review and editing.

\section{Conflict of Interest}

The author(s) declare that they have no known competing financial or non-financial, professional, or personal conflicts that could have appeared to influence the work reported in this paper.

\section{Acknowledgements}

The authors would like to thank Dr. Fabio Fiorentino from the Institute for Marine Biological Resources and Biotechnologies (IRBIM) for support and valuable comments on the manuscript. We are grateful to anonymous reviewers and to the editor for their valuable suggestions to improve the quality of the paper.

\section{References}

Acarli, D., Kale S \& Çakir, K. (2018). A new maximum length for the garfish, Belone belone (Linnaeus, 1761) in the coast of Gökçeada Island (Aegean Sea, Turkey). Cahier de Biologie Marine, 59(4), 385-389. https://doi.org/10.21411/CBM.A.55A28635

Bauchot, M.L. (1987). Vertébrés, Poissons osseux. In W. Fischer, M.L. Bauchot \& M. Scheinder (Eds), Méditerranée et mer Noire. Zone de pêche 37. Fiches FAO d'Identification des Espèces pour les Besoins de la Pêche Vol. 2 (pp. 976-980). Rome.

Bedoui, F.R., Gharbi, H. \& Abed, A. (2002). Période de reproduction et maturité sexuelle de Belone belone 
gracilis (Belonidae) des côtes Est et Sud. Bulletin de I'Institut National Scientifique et Technique d'Océanographie et de Pêche de Salammbô, 29, 11-15.

Bilgin, S, Taşçı, B. \& Bal, H. (2014 a). Populations dynamics of the garfish, Belone euxini (Belonidae: Belone) from the south east Black Sea. Journal of the Marine Biological Association of the United Kingdom, 94(8), 1687-1700. https://doi.org/10.1017/S0025315414000769

Bilgin, S., Taşçı, B. \& Bal, H. (2014 b). Reproduction Biology of the Garfish, Belone euxini Günther, 1866 (Belonidae: Belone) in the Southeast Black Sea. Turkish Journal of Fisheries and Aquatic Sciences, 14, 623-631. https://doi.org/10.4194/1303-2712-v14_3_04

Borges, T. C., Olim, S. \& Erzini, K. (2003). Weight-length relationships for fish species discarded in commercial fisheries of the Algarve (Southern Portugal). Journal of Applied Ichthyology, 19(6), 394-396. https://doi.org/10.1111/j.1439-0426.2003.00480.x

Ceyhan, T., Samsun, O. \& Akyol, O. (2019). Age, Growth and Mortality of Garfish, Belone euxini Günther, 1866 in the Central Black Sea, Turkey. Pakistan Journal of Zoology, 51(1), 273-278. https://doi.org/10.17582/journal.pjz/2019.51.1.273.27 8

Châari, M., Feki, M. \& Neifar, L. (2015). Metazoan parasites of the Mediterranean garfish Belone belone gracilis (Teleostei: Belonidae) as a tool for stock discrimination. Open Journal of Marine Science, 5(3), 324-334. https://doi.org/10.4236/ojms.2015.53027

Chen, Y., Jackson, D.A. \& Harvey, H.H. (1992). A comparison of von Bertalanffy functions in modelling fish growth data. Canadian Journal of Fisheries and Aquatic Sciences, 49(6), 1228-1235. https://doi.org/10.1139/f92-138

Collette, B.B. \& Parin, N.V. (1970). Needlefishes (Belonidae) of the eastern Atlantic Ocean. Atlantide Report, 11, $60 \mathrm{p}$.

Collette, B.B. \& Parin, N.V. (1986). Belonidae. In P.J.P. Whitehead, M.L. Bauchot, J.C. Hureau, J. Nielsen \& E. Tortonese (Eds), Fishes of the North Eastern Atlantic and the Mediterranean Vol. 2 (pp. 604-609). Paris, Unesco.

Collette, B.B. (2003). Family Belonidae (Bonaparte, 1832) needlefish. Annotated checklist of fish. Occasional Papers of the California Academy of Sciences, 16, 1-22.

Dominguez-Petit, R., Korta, M., Saborido-Rey, F., Murua, H., Sainza, M. \& Piñeiro, C. (2008). Changes in size at maturity of European hake Atlantic populations in relation with stock structure and environmental regimes. Journal of Marine Systems, 71(3), 260-278. https://doi.org/10.1016/j.jmarsys.2007.04.004

Dalgaard, P., Madsen, H.L., Samieian, N. \& Emborg, J. (2006). Biogenic amine formation and microbial spoilage in chilled garfish (Belone belone belone) - effect of modified atmosphere packaging and previous frozen storage. Journal of Applied Microbiology, 101(1), 80-95. https://doi.org/10.1111/j.1365-2672.2006.02905.x.

Dorman, J.A. (1988). Diet of the garfish, Belone belone (L.) from Courtmacsherry Bay, Ireland. Journal of Fish Biology, 33(3), 339-346.

https://doi.org/10.1111/J.1095-8649.1988.TB05476.X

Dorman, J.A. (1989). Some aspects of the biology of the garfish Belone belone (L.) from Southern Ireland. Journal of Fish Biology, 35(5), 621-629. https://doi.org/ 10.1111/j.1095-8649.1989.tb03014.x

Dorman, J.A. (1991). Investigations on to the biology of the garfish, Belone belone (L.), in Swedish waters. Journal of Fish Biology, 39(1), 59-69. https://doi.org/10.1111/j.1095-8649.1991.tb04341.x

Engelhard, G.H. \& Heino M. (2004). Maturity changes in Norwegian spring spawning herring before, during, and after a major population collapse. Fisheries Research, 66(2), 299-310.

https://doi.org/10.1016/S0165-7836(03)00195-4

Fehri-Bedoui, R. \& Gharbi, H., (2004). Contribution à l'étude de la croissance et l'âge de Belone belone (Belonidae) des côtes Est de la Tunisie. Rapport Communication Internationale Mer Méditerranée, 37, 352.

Francis, R.I.C.C., 1990. Back-calculation of fish length: a critical review. Journal of Fish Biology, 36(6), 883-902. https://doi.org/10.1111/j.1095-8649.1990.tb05636.x

Fricke, R., Bilecenoglu, M. \& Sari, H. M. (2007). Annotated checklist of fish and lamprey species (Gnathostomata and Petromyzontomorphi) of Turkey, including a Red List of threatened and declining species. Stuttgarter Beiträge zur Naturkunde, 706 A, 1-172

Froese, R. \& Pauly, D. (Eds) (2021). Fishbase, World Wide Web electronic publication. Available at WWW.fishbase.org.

Gayanilo, F.C., Sparre, P. \& Pauly, D., (2006). FAO-ICLARM Stock Assessment Tools II (Fisat II) Revised versionUser's Guide. 168 p. Computerized Information Series (Fisheries), 8. Rome: FAO.

Jardas, I. (1996). Jadranska ihtiofauna. S`kolska knjiga, Zagreb $533 \mathrm{p}$.

Kalayci, F. \& Yeşilçiçek, T. (2012). Length based seasonal growth of the garfish, Belone belone (Linnaeus, 1761) (Belonidae), in the southeast Black Sea. African Journal of Biotechnology, 11(35), 874. https://doi.org/10.5897/AJB11.1560

King, M. (1995). Fishery Biology, Assessment and Management. 341 p. Oxford, UK: Blackwell Sciences Ltd.

Morales-Nin, B., Canha, A., Casas, M., Figuereido, I., Gordo, L.S, Gordon, J.M., Gouveia, D., Mckurdy, W.J., Panfili, J., Meunier, F.J. \& Pontual, H. (2002). Preparation of calcified structures. In J. Panfili, H. Pontual, H. Troadec \& P. J. Wright (Eds), Manual of Fish Sclerochronology (pp. 331-357). Brest, France, Ifremer \& IRD coedition.

Nedelec, C. (1975). FAO Catalogue of Small-scale Fishing Gear. Fishing News (Books) Ltd., England., 191 p.

Pankhurst, W. \& Munday P. L (2011). Effects of climate change on fish reproduction and early life history stages. Marine and Freshwater Research, 62(9), 1015-1026.

Pauly, D. \& Munro, J.L. (1984). Once more on the comparison of growth in fish and invertebrates. Fishbyte, 2(1), 21.

Polat N., Inceismail Y., Yılmaz S. \& Bostanc D. (2009). Age Determination, Age-Length and Length-Weight relationships of garfish (Belone belone L., 1761) in the Black Sea (Samsun). Journal of Fisheries Sciences com, 3(3), 187-198. https://doi.org/10.3153/jfscom.2009023

Rosenthal, H. \& Fonds, M. (1973). Biological observations during rearing experiments with the Garfish Belone belone. Marine Biology, 21, 203-218. https://doi.org/10.1007/BF00355251

Samsun, O. (1996). Sinop (Karadeniz) Zargana (Belone belone euxini, Günther, 1866) balığı populasyonuna ilişkin (1995-1996) büyüme karakteristikleri değişimlerinin I'zlenmesi. Ege Üniversitesi Su Ürünleri Dergisi, 12, 347355.

Samsun, O., Özdamar, E., Erkoyuncu, İ., (1995): Sinop Yöresinde Avlanan Zargana (Belone belone euxini, Günther, 1866) Balığının Bazı Balıkçıık Biyolojisi Parametreleri ile Et Veriminin Araştırılması. Doğu Anadolu Bölgesi II. Su Ürünleri Semp. Atatürk 
Üniversitesi Ziraat Fakültesi Gıda Mühendisliği Bölümü, 14-16 Haziran, 1-14 (in Turkish).

Samsun, O., Samsun, S., Bilgin, S. \& Kalayci, F. (2006). Population biology and status of exploitation of introduced garfish Belone belone euxini (Günter, 1866) in the Black Sea. Journal of Applied Ichthyology, 22(5), 353-356. https://doi.org/10.1111/j.1439-0426.2006.00751.x

Scherrer, B. (1984). Biostatistique. G. Morin (Editor), Boucherville, Montréal, 850 pp.

Sinovčvić, G. (1978). On the ecology of anchovy, Engraulis encrasicolus (L.), in the Central Adriatic. Acta Adriatica, 19(2), 1-32

Sinovčvić, G., Franičević, M., Zorica, B. \& Čikeš-Keč, V. (2004). Length-weight and lenght-length relationships for 10 pelagic fish species form Adriatic Sea (Croatia). Journal of Applied Ichthyology, 20(2), 156-158. https://doi.org/10.1046/j.1439-0426.2003.00519.x

Sinovčvić, G., Čikeš Keč, V. \& Zorica, B. (2008). Population structure, size at maturity, condition of sardine, Sardina pilchardus (Walb., 1792) in the nursery ground of the eastern Adriatic Sea (Krka River Estuary, Croatia). Estuarine, Coastal and Shelf Science, 76(4), 739-744. https://doi.org/ 10.1016/j.ecss.2007.07.037

Sparre, P. \& Venema, S.C. (1998). Introduction to tropical fish stock assessment, Part I: Manual. FAO Fisheries Technical Paper, 306, 1.

Tu, C.Y., Chen, K.T. \& Hsieh, C. H. (2018). Fishing and temperature effects on the size structure of exploited fish stocks. Scientific Reports, 8(1), 7132. https://doi.org/ 10.1038/s41598-018-25403-x

Türker Çakır, D. \& Zengin, K. (2013). Occurrence of Tylosurus acus imperialis (Rafinesque, 1810) (Osteichthyes:
Belonidae) in Edremit Bay (Northern Aegean Sea). Journal of Applied Ichthyology, 29(3), 671-672. https://doi.org/ 10.1111/jai.12178

Uçkun, D., Akalin, S., Taskavak, E. \& Togulga, M. (2004). Some biological characteristics of the garfish (Belone belone L., 1761) in Izmir Bay, Aegean Sea. Journal of Applied Ichthyology, 20(5), 413-416. https://doi.org/10.1111/j.1439-0426.2004.00592.x

Whitehead, P.J.P., Bauchot, M.L., Hureau, J.C., Nielson, J. \& Tortonese, E. (1986). Fishes of the North-eastern Atlantic and the Mediterranean vol. 3 (pp. 1013-1473). Paris, Unesco.

Wright, P.J., Panfili, J., Morales-Nin, B. \& Geffen, A.J. (2002). Otoliths. In J. Panfili, H. Pontual \& H. Troadec (Eds), Manual of fish sclerochronology (pp. 31-57). Brest, France.

Ifremer-IRD co-edition.

Yüce, R. (1970). Zargana Baliği Belone belone (L.) nin Biolojisi. Hidrobiyoloji Arastirma Enstitüsü Yayinlari, 75, 1-25.

Zar, J.H. (1996). Biostatistical Analysis. 3rd Edition, Prentice Hall, Inc., Upper Saddle River. 662 p.

Zorica, B., Sinovčvić, G \& Čikeš Keč, V. (2011). The reproductive cycle, size at maturity and fecundity of garfish (Belone belone, L. 1761) in the eastern Adriatic Sea. Helgoland Marine Research, 65(4), 435-444. https://doi.org/10.1007/s10152-010-0233-0

Zorica, B. \& Čikeš Keč, V. (2011). Phenotypic characteristic of garfish Belone belone (Linnaeus, 1761) in the Adriatic Sea. Acta Adriatica, 52(2), 269-278.

Zorica, B. \& Čikeš Keč, V. (2013). Age, growth and mortality of the garfish, Belone belone (L. 1761) in the Adriatic Sea. Journal of the Marine Biological Association of the United Kingdom, 93(2), 365-372. https://doi.org/10.1017/S002531541200149X 